\title{
MUTAGENIC EFFECTS OF SODIUM AZIDE ON THE GERMINATION IN RICE (Oryza sativa L. cv. INPAGO UNSOED 1)
}

\author{
BAGUS HERWIBAWA AND FLORENTINA KUSMIYATI
}

\author{
Plant Physiology and Breeding Laboratory, Department of Agriculture, \\ Faculty of Animal and Agricultural Sciences, Diponegoro University \\ Tembalang Campus, Semarang 50275, Central Java, Indonesia \\ email: bagus.herwibawa@live.com
}

\begin{abstract}
The available natural diversity highly limits the effort to improve the production of upland-rice with delicious and aromatic flavors. However, the mutagenesis can help improving the natural diversity. The aromatic-upland rice seeds, cv. Inpago Unsoed 1, were soaked in solution of NaN3 with the doses of $0 \mathrm{mM}, 1 \mathrm{mM}, 2 \mathrm{mM}, 3 \mathrm{mM}, 4 \mathrm{mM}, 5 \mathrm{mM}, 6 \mathrm{mM}, 7 \mathrm{mM}, 8 \mathrm{mM}, 9 \mathrm{mM}$, and $10 \mathrm{mM}$, in four replications in completely randomized design. The observation included LD50, germination percentage at first-count and final-count. Data were tabulated and analyzed with CurveExpert 1.4 software for LD50, and generalized linear model in the PROC-GLM procedure of SAS 9.1 software. The means were generated and compared through Dunnett option, at probability level of $5 \%$, in order to determine the difference in means between mutated and non-mutated seeds. The results showed that the attributes of rice physiology affected by mutagenesis were sensitivity of rice to NaN3 with $L D 50$ at $8.84 \mathrm{mM}$, and significantly effect of NaN3 on the decreasing capacity of seed germination at > $6 \mathrm{mM}$ for first count, and $>7 \mathrm{mM}$ for final count.
\end{abstract}

Keywords: germination, inpago unsoed 1, median lethal dose, rice, sodium azide.

\section{INTRODUCTION}

Rice is the staple food for more than $95 \%$ of Indonesian people, in which the number of people is predicted to reach 263 million in 2020, so the need for rice will increase to 35.97 million ton (Anindita et al., 2016). Besides, current society prefers specific rice type for a number of reasons, like delicious and aromatic flavors (Calingacion et al., 2014). In 2011, Inpago Unsoed 1 successfully met the need of people for rice with delicious and aromatic flavors, through the breeding of upland-rice which is adaptive in the dryland (Gusmiatun, 2015).

In Indonesia, the width of dry land reaches $22,307,120$ ha, so it is very potential to increase the production of upland rice (Dariah et al., 2012). Besides, the effort to increase rice production can be performed through crossing, and it is very potential to improve the nature of heredity (Luo, 2010). However, the available natural diversity often becomes limit in the crossing (Shu, 2009). One of ways to improve natural diversity is through mutagenesis (Rustikawati et al., 2012). Mutagenesis with the treatment of sodium azide $\left(\mathrm{NaN}_{3}\right)$ has been reported to improve the resistance under drought stress from -0.0021 $\mathrm{MPa}$ to $-0.0077 \mathrm{MPa}$ (He et al., 2009; Aurabi et al., 2012).

The resistance traits under the drought stress are obtained after the specific selection for some generations (Mustikarini et al., 2017), in which the selection can be performed since the germination phases (Harding et al., 2012). The germination is a physiological process which is very complex with comprehensive genetic background and reflects the quality of seed related to the tolerance of plant under unfavorable-bad condition (Wang et al., 2010). Therefore, this research aims to know the effect of sodium azide on the germination physiology of rice, cv. Inpago Unsoed 1. This study is expected to give initial information in the productionincreasing program of upland rice with delicious and aromatic flavors.

\section{MATERIALS AND METHODS}

\section{Plant material}

The aromatic-upland rice seeds (Oryza sativa L. Cv. Inpago Unsoed 1) were obtained from Laboratory of Biotechnology and Plant Breeding, Faculty of Agriculture, Jenderal Soedirman University, Purwokerto, Indonesia. The seeds were submitted to treatment of $\mathrm{NaN}_{3}$.

\section{Mutagenesis}

Seeds mutagenesis were performed in Laboratory of Physiology and Plant Breeding, Faculty of Animal and Agricultural Sciences, Diponegoro University. The healthy seeds were soaked in solution of $\mathrm{NaN}_{3}$ with doses of 
$0 \mathrm{mM}, 1 \mathrm{mM}, 2 \mathrm{mM}, 3 \mathrm{mM}, 4 \mathrm{mM}, 5 \mathrm{mM}, 6$ $\mathrm{mM}, 7 \mathrm{mM}, 8 \mathrm{mM}, 9 \mathrm{mM}$, and $10 \mathrm{mM}$, for 6 hours, at a temperature of around $25{ }^{\circ} \mathrm{C}$, in 0.1 $\mathrm{M} \mathrm{KH_{2 }} \mathrm{PO}_{4}(\mathrm{pH}=3.5)$. After mutagenesis, the seeds were washed for 1.5 hours in the running water at a temperature of around 15 ${ }^{0} \mathrm{C}$ (Shin and Jeung, 2011).

\section{Germination}

The seeds from mutagenesis were germinated under the natural condition in soil in plastic seedling tray, in four replications in Completely Randomized Design (CRD). All trays were supplied with water every day in order to maintain soil moisture on the field capacity during experiment period.

\section{Physiological attributes of rice as affected by mutagenesis}

The seeds from mutagenesis were considered germinating when the length of radicle is $>2 \mathrm{~mm}$. Median lethal dose $\left(L_{50}\right)$ was calculated based on the number of seeds surviving in different mutagen doses (Roslim et al., 2015).

The germination percentage (GP) were calculated at $5^{\text {th }}$ day (first count) and $14^{\text {th }}$ day (final count) after germinated, following the formula of Marcu et al. (2013), in which NT = proportion of the germinating seeds in every treatment; $\mathrm{N}=$ number of seeds used in bioassay.

$$
\mathrm{GP}(\%)=\frac{\mathrm{NT} \times 100}{\mathrm{~N}}
$$

\section{Statistical analysis}

Data were tabulated and analyzed with CurveExpert 1.4 software for $L D_{50}$, and generalized linear model in the PROC-GLM procedure of SAS 9.1 software. The means were generated and compared through Dunnett option, at probability level of $5 \%$, in order to determine the difference in means between mutated and non-mutated seeds.

\section{RESULTS AND DISCUSSION}

$\mathrm{NaN}_{3}$ is the chemical mutagen which is known to improve the genetic diversity, as its trait is very mutagenic (Dewi et al., 2016). Effectiveness and efficiency of mutagenic in general increase with the increasing mutagen dose (Sharma et al., 2010), in which the maximum amount of cell mutant is predicted in the range of $L_{50}$ (Gaswanto et al., 2016).

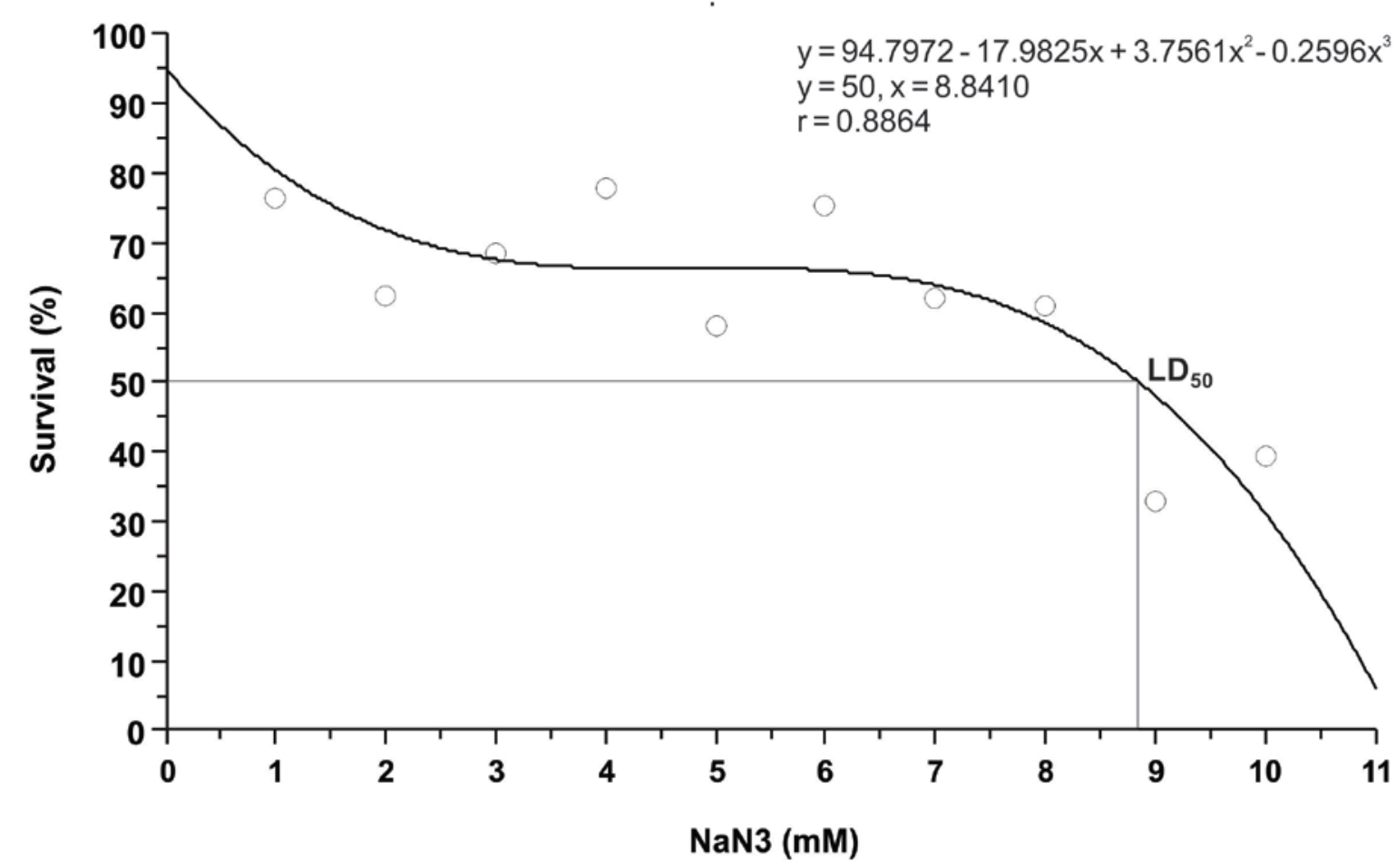

Figure 1. Dose - response curve with polynomial fit

Dose-response curve shows the sensitivity of rice cV. Inpago Unsoed 1 on $\mathrm{NaN}_{3}$ with $\mathrm{LD}_{50}$ at $8.84 \mathrm{mM}$ (Figure 1). Different from research of Omoregie et al. (2014), in which $\mathrm{LD}_{50}$ of rice cv. Faro 44, Faro 52, Faro 57,
Nerica L-34 and Nerica L-47 are estimated at $4.92 \mathrm{mM}$. In other species, LD $_{50}$ can be different, such as musk-okra (Abelmoschus moschatus L.) at $15.38 \mathrm{mM}$ (Warghat et al., 2011), onion (Allium cepa L.) at 76.90-139.95 
mM (Joshi et al., 2011), maize (Zea mays L.) at $40 \mathrm{mM}$ (Gnanamurthy et al., 2012), and garlic (Allium sativum L.) at 3.23-16.61 mM (Mahajan et al., 2015).

The difference of $\mathrm{LD}_{50}$ among genotypes depends on its sensitivity on mutagen, related to production of free radicals (Roslim et al., 2015), in which free radicals of oxygen from the accumulation of azide derivative of peroxidase is the secondary mutagen responsible for substituting DNA base (Gruszka et al., 2012).

The substitution can be expressed as a variation of germination percentage (Table 1). According to Milosevic et al. (2010), the germination percentage is an indicator of seed quality, which can be used to predict the growth of plant when the condition in the field is nearly ideal.

Table 1. Effects of $\mathrm{NaN}_{3}$ on germination percentages (GP) were taken at $5^{\text {th }}$ day (first count) and $14^{\text {th }}$ day (final count) of rice (Oryza sativa L. cv. Inpago Unsoed 1)

\begin{tabular}{ccc}
\hline $\begin{array}{c}\mathrm{NaN}_{3} \\
(\mathrm{mM})\end{array}$ & $\begin{array}{c}\text { First Count } \\
(\%)\end{array}$ & $\begin{array}{c}\text { Final Count } \\
(\%)\end{array}$ \\
\hline 0 & 100.00 & 100.00 \\
1 & 76.50 & 93.00 \\
2 & $62.50^{\star}$ & 80.50 \\
3 & 68.50 & 76.50 \\
4 & 78.00 & 94.50 \\
5 & $58.00^{*}$ & 66.00 \\
6 & 75.50 & 78.50 \\
7 & $62.00^{*}$ & 71.50 \\
8 & $61.00^{\star}$ & $68.00^{\star}$ \\
9 & $33.00^{*}$ & $60.00^{\star}$ \\
10 & $39.50^{\star}$ & $52.50^{\star}$ \\
\hline
\end{tabular}

Data were transformed by arcsine prior to analysis; nontransformed data are presented; * Significant difference $(p<0.05)$

Seed germination after mutagenesis (1-10 mM) states that maximum percentage of germination can be observed at control (0 $\mathrm{mM})$. As shown in Table 1, the first-count decreases with the increasing mutagen dose, in which in the maximum decrease, $33.00 \%$, the observed germination percentage is at 9 $\mathrm{mM}$. It shows that the increasing dose of mutagen reduces the germination percentage, but the decrease is not in line with the increasing dose of mutagen. Statistical analysis stated that dose higher than $6 \mathrm{mM}$ significantly causes the decreasing capacity of seed germination at $5^{\text {th }}$ day after germination.

The potency of seed germination expressed through final-count (Table 1), states the decreasing pattern similar with the dose increase, like first-count. Dose of 1-7 mM causes the decreasing percentage of germination insignificantly, but the inhibition is significant statistically on the potency of germination noted at higher dose, in which final-count decreases by $68.00 \%$ for $8 \mathrm{mM}$, and $60 \%$ for $9-\mathrm{mM}$, compared with control. The highest inhibition from germination process, $52.50 \%$, is noted at $10 \mathrm{mM}$.

The decreasing percentage of germination as result of the increasing mutagen dose with nonlinear decrease was also reported by Sasikala and Kalaiyarasi (2010). However, different research was reported by Anbarasan et al. (2013), in which the germination percentage decreases along with the increase of mutagen dose. According to Shah et al. (2008), the decreasing percentage of germination as the effect of mutagen treatment, is caused by the increasing activity of free radicals encouraging the death of seeds.

The effect of mutagen causes quantitative and qualitative deviations. The qualitative deviation is indicated by the albino seedling at $5 \mathrm{mM}$ (Figure 2). $\mathrm{NaN}_{3}$ is actually reported effective to make rice seedling albino (Ando and Montalvan, 2001). The albino condition is caused by the mistakes in the chloroplast genome replication, so it makes chlorophyll abnormal (Lin et al., 2008).

Albino is the chlorophyll deficiency seen as a white colour and indicates that there is no pigment, so plant will die 7-14 days after germination (Warghat et al., 2011). However, albino rice seedling in this study can live more than 14 days after germination. According to Herwibawa et al. (2014), the chlorophyll deficiency which does not cause the death more than 14 days after germination is not a perfect albino. However, many seedlings from seeds treated at high dose $(\geq 8 \mathrm{mM})$ can survive, so it is very possible for further investigation.

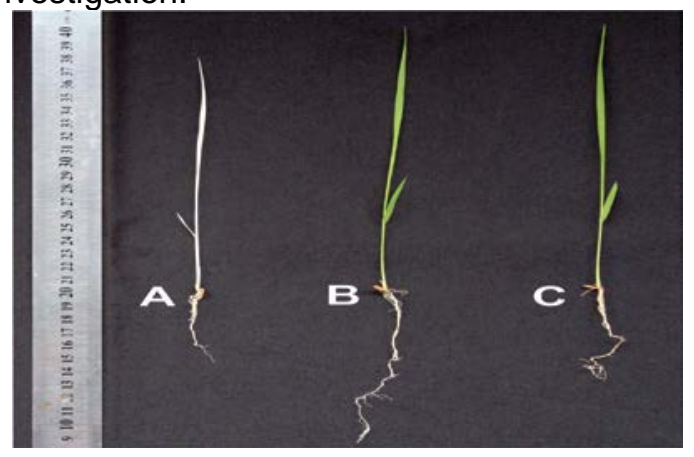

Figure 2. Rice seedlings at $14^{\text {th }}$ day after germination. $A=$ white rice seedling (albino) $\left(\mathrm{NaN}_{3} 5 \mathrm{mM}\right) ; \mathrm{B}=$ green rice seedling (after mutagenesis) $\left(\mathrm{NaN}_{3} 5\right.$ $\mathrm{mM}$ ); $\mathrm{C}=$ green rice seedling (control) $\left(\mathrm{NaN}_{3} \mathrm{O} \mathrm{mM}\right)$ 


\section{CONCLUSIONS}

The physiological attributes in rice cv. Inpago Unsoed 1 affected by mutagenesis, shows the sensitivity on $\mathrm{NaN}_{3}$ with $\mathrm{LD}_{50}$ at 8.84 $\mathrm{mM}$. $\mathrm{NaN}_{3}$ significantly affects the decreasing capacity of seed germination at $>6 \mathrm{mM}$ for first-count, and $>7 \mathrm{mM}$ for final-count. The surviving seedlings are very possible for further investigation.

\section{ACKNOWLEDGEMENTS}

Authors thank Professor Totok Agung Dwi Haryanto, Ph.D. (the breeder of rice cv. Inpago Unsoed 1) for providing seeds. Support and laboratory facility provided by Dr. Florentina Kusmiyati, Head of Laboratory of Physiology and Plant Breeding, Diponegoro University.

\section{REFERENCES}

Anbarasan, K., R. Rajendran, D. Sivalingam, M. Anbazhagan, and AL.A. Chidambaram. 2013. Effect of Gamma Radiation on Seed Germination and Seedling Growth of Sesame (Sesame indicum L.) var. TMV3. International Journal of Research in Botany, 3 (2) : 27-29.

Ando, A. and R. Montalvan. 2001. Gamma Ray Radiation and Sodium Azide $\left(\mathrm{NaN}_{3}\right)$ Mutagenic Efficiency in Rice. Crop Breeding and Applied Biotechnology, 1 (4) : 339-346.

Anindita, R., A. Q. Pudjiastuti, N. Baladina, and B. Setiawan. 2016. Food self sufficiency scenario of Indonesia: The impact of land expansion and increasing food prices. Advances in Environmental Biology, 10 (10): 97102

Aurabi, A.K., K.M. Ibrahim, and S.A. Yousif. 2012. Induction of Genetic Variation for Drought Tolerance in Two Rice Cultivars Amber 33 and Amber Baghdad. Iraqi Journal of Biotechnology, 11 (2) : 270-281.

Calingacion, M., A. Laborte, A. Nelson, A. Resurreccion, J.C. Concepcion, V.D. Daygon, R. Mumm, R. Reinke, S. Dipti, P.Z. Bassinello, J. Manful, S. Sophany,K.C. Lara, J. Bao, L. Xie, K. Loaiza, A. El-hissewy, J. Gayin, N. Sharma, S. Rajeswari, S. Manonmani, N.S. Rani, S. Kota, S.D. Indrasari, F. Habibi, M. Hosseini, F. Tavasoli, K. Suzuki, T. Umemoto, C. Boualaphanh, H.H. Lee, Y.P. Hung, A.
Ramli, P.P. Aung, R. Ahmad, J.I. Wattoo, E. Bandonill, M. Romero, C.M. Brites, R. Hafeel, H.S. Lur, K. Cheaupun, S. Jongdee, P. Blanco, R. Bryant, N.T. Lang, R.D. Hall, M. Fitzgerald. 2014. Diversity of Global Rice Markets and the Science Required for Consumer-Targeted Rice Breeding. PloS ONE, 9 (1): e85106 doi: 10.1371/journal.pone.0085106

Dariah, A., B. Kartiwa, N. Sutrisno, K. Suradisastra, M. Sarwani, H. Soeparno, dan E. Pasandaran. 2012. Prospects for Agriculture of Dry Land Towards Food Sovereignty. Badan Penelitian dan Pengembangan Pertanian, Kementerian Pertanian. Bogor, Indonesia (in Indonesia).

Dewi, K., G. Meidiana, Sudjino, and Suharyanto. 2016. Effects of sodium azide (NaN3) and cytokinion vegetative growth and yield of black rice plant (Oryza sativa L. 'Cempo Ireng'). AIP Conference Proceedings 1775 doi: $10.1063 / 1.4958549$

Gaswanto, R., M. Syukur, B.S. Purwoko, and S.H. Hidayat. 2016. Induced mutation by gamma rays irradiation to increase chilli resistance to Begomovirus. Agrivita Journal of Agricultural Science, 38 (1): 24-32

Gnanamurthy, S., D. Dhanavel, M. Girija, P. Pavadai, and T. Bharathi. 2012. Effect of chemical mutagenesis on quantitative traits of maize (Zea mays L.). International Journal of Research in Botany, 2(4): 34-36.

Gruszka, D., I. Szarejko, and M. Maluszynski. 2012. Sodium Azide as a Mutagen. In: Plant Mutation Breeding and Biotechnology. CABI International, Wallingford, UK. pp. 159-166.

Gusmiatun. 2015. Growth and Yield of Some Upland Rice Varieties in Ogan Ilir South Sumatra. Prosiding Seminar Nasional Lahan Suboptimal 2015, Palembang 08-09 October 2015 (in Indonesian).

Harding, S.S., S.D. Johnson, D.R. Taylor, C.A. Dixon, and M.Y. Turay. 2012. Effect of Gamma Rays on Seed Germination, Seedling Height, Survival Percentage and Tiller Production in Some Rice Varieties Cultivated in Sierra Leone. American Journal of Experimental Agriculture, 2 (2) : 247-255.

He, J., Y. Hu, W.C. Li, and F.L. Fu. 2009. Drought Tolerant Mutant Induced by Gamma Ray and Sodium Azide from 
Maize Calli. Maize Genetics Cooperation Newsletter, 83 : 53-55.

Herwibawa, B., T.A.D. Haryanto, and Sakhidin. 2014. The Effect of Gamma Irradiation and Sodium Azide on Germination of Some Rice Cultivars. Agrivita Journal of Agricultural Science, 36 (1) : 36-32.

Joshi, N., A. Ravindran, and V. Mahajan. 2011. Investigations on Chemical Mutagen Sensitivity in Onion (Allium cepa L.). International Journal of Botany, 7 (3): 243-248

Lin, C, N. Liu, D. Liao, J. Yu, C. Tsao, C. Lin, C. Sun, W. Jane, H. Jane, J. J. Chen, E.Lai, N. Lin, W. Chang, and C. Lin. 2008. Differential Protein Expression of Two Photosystem II Subunits, PsbO and PsbP, in an Albino Mutant of Bambusa edulis with Chloroplast DNA Aberration. Journal of the American Society for Horticultural Science, 133 (2) : $270-277$.

Luo, L.J. 2010. Breeding for water-saving and drought-resistance rice (WDR) in China. Journal of Experimental Botany, 61 (13): 3509-3517.

Mahajan, V., A. Devi, A. Khar, and K.E. Lawande. 2015. Studies on Mutagenesis in Garlic Using Chemical Mutagens to Determine Lethal Dose $\left(L_{50}\right)$ and Create Variability. Indian Journal of Horticulture, 72 (2): 289-292

Marcu, D., G. Damian, C. Cosma, and V. Cristea. 2013. Gamma Radiation Effects on Seed Germination, Growth and Pigment Content, and ESR Study of Induced Free Radicals in Maize (Zea mays). Journal of Biological Physics, 39 (4): 625-634.

Milosevic, M., M. Vujakovic, and D. Karagic. 2010. Vigour Tests as Indicators of Seed Viablity. Genetika, 42(1): 103118

Mustikarini, E.D., N.R. Ardiarini, N. Basuki, and Kuswanto. 2017. Selection Strategy of Drought Tolerance on Red Rice Mutant Lines. Agrivita Journal of Agricultural Science, 39 (1): 91-99.

Omoregie, U.E., J.K. Mensah, and B. Ikhajiagbe. 2014. Germination Response of Five Rice Varieties Treated with Sodium Azide. Research Journal of Mutagenesis, 4 (1): 14-22

Roslim, D.I., Herman, and I. Fiatin. 2015. Lethal Dose $50\left(L_{50}\right)$ of Mungbean (Vigna radiata L. Wilczek) Cultivar Kampar. SABRAO Journal of Breeding and Genetics, 47(4): 510-516

Rustikawati, E. Suprijono, A. Romeida, C. Herison, and S.H. Sutjahjo. 2012.
Identification of M4 Gamma Irradieated Maize Mutant Based on RAPD Markers. Agrivita Journal of Agricultural Science, 34 (2) : 162-166.

Sasikala and Kalaiyarasi. 2010. Sensitivity of Rice Varieties to Gamma Irradiation. Electronic Journal of Plant Breeding, 1 (4) : $885-889$.

Shah, T.M., J.I. Mirza, M.A. Haq, and B.M Atta. 2008. Radio Sensitivity of Various Chickpea Genotypes in $\mathrm{M}_{1}$ Generation I-Laboratory Studies. Pakistan Journal of Botany, 40 (2) : 649 - 665.

Sharma, A., P. Plaha, R. Rathour, V. Katoch, Y. Singh and G.S. Khalsa. 2010. Induced Mutagenesis for Improvement of Garden Pea. International Journal of Vegetable Science, 16 (1): 60-72

Shin, Y.S., and J.U. Jeung. 2011. Genetic Diversity Estimation of The Rice Mutant Lines Induced by Sodium Azide. Korean Journal of Breeding Science, 43 (1) : 23-31.

Shu, Q. Y. 2009. A Summary of The International Symposium on Induced Mutations in Plants; In : Q.Y. Shu (Ed.). Induced Plant Mutations in Genomics Era. pp : 51-58 Proceedings of an International Joint FAO/IAEA Symposium, International Atomic Energy Agency, Vienna, Austria.

Wang, Z., J.Wang, Y. Bao, F. Wang, and $\mathrm{H}$. Zhang. 2010. Quantitative Trait Loci Analysisi for Rice Seed Vigor during The Germination Stage. Biomedicine and Biotechnology, 11 (12) : 958-964

Warghat, A.R., N.H. Rampure, and P. Wagh. 2011. Effect of Sodium Azide and Gamma Rays Treatments on Percentage Germination, Survival, Morphological Variation and Chlorophyll Mutation in Musk Okra (Abelmoschus moschatus L.). International Journal of Pharmacy and Pharmaceutical Sciences, 3 (5): 483486 
Mutagenic Effects of Sodium Azide (Herwibawa, Kusmiyati) 